$\begin{array}{ll} & \text { Etnográfica } \\ \text { etnográfica } & \text { Revista do Centro em Rede de Investigação em }\end{array}$

Antropologia

vol. $14(1) \mid 2010$

Vol. $14(1)$

\title{
Clara Sarmento, Cultura popular portuguesa: práticas, discursos e representações
}

\section{Ricardo Campos}

\section{(2)enEdition}

\section{Journals}

\section{Edição electrónica}

URL: https://journals.openedition.org/etnografica/374

DOI: 10.4000/etnografica.374

ISSN: 2182-2891

\section{Editora}

Centro em Rede de Investigação em Antropologia

\section{Edição impressa}

Data de publição: 1 fevereiro 2010

Paginação: 206-208

ISSN: 0873-6561

\section{Refêrencia eletrónica}

Ricardo Campos, «Clara Sarmento, Cultura popular portuquesa: práticas, discursos e representações», Etnográfica [Online], vol. 14 (1) | 2010, posto online no dia 20 julho 2012, consultado o 11 fevereiro 2022. URL: http://journals.openedition.org/etnografica/374; DOI: https://doi.org/10.4000/etnografica. 374

Este documento foi criado de forma automática no dia 11 fevereiro 2022

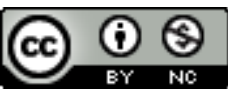

Etnográfica is licensed under a Creative Commons Attribution-NonCommercial 4.0 International License. 


\title{
Clara Sarmento, Cultura popular portuguesa: práticas, discursos e representações
}

\author{
Ricardo Campos
}

\section{REFERÊNCIA}

Clara Sarmento, Cultura popular portuguesa: práticas, discursos e representações, Porto, Edições Afrontamento, 496 páginas.

1 A obra de Clara Sarmento Cultura Popular Portuguesa: Práticas, Discursos e Representações obteve o prémio CES 2007 para Jovens Cientistas Sociais de Língua Oficial Portuguesa. Apesar de o título não o indicar claramente, este livro resulta de uma investigação tendo por objecto central o moliceiro da região de Aveiro. O moliceiro é um tipo de embarcação regional cuja função original era a da recolha do moliço, substância constituída por plantas aquáticas tradicionalmente empregues para a fertilização dos campos agrícolas. A principal originalidade desta embarcação, que é, em larga medida, a causa da sua promoção como artefacto estético e cultural de valor, reside nos painéis decorativos que ostenta e que têm sido observados e estudados como autênticas expressões de "arte popular". Apesar da sua existência longa, o barco moliceiro esteve, por diversas razões que são minuciosamente detalhadas pela autora, perto da extinção nas décadas de 70 e 80 do século XX. Nas últimas duas décadas assistimos a um ressurgimento do barco moliceiro que não é indiferente ao interesse que este tem despertado junto de entidades públicas e privadas, atentas ao potencial simbólico e económico deste emblema regional.

2 Esta é uma pesquisa de fôlego, alicerçada numa extensa e bem documentada informação proveniente de diferentes fontes orais, literárias e iconográficas, produzidas por diversos agentes individuais e colectivos, em contextos históricos variados. A autora traça um percurso histórico em que descreve pormenorizadamente a 
evolução do moliceiro - enquanto artefacto simbólico e funcional -, bem como das representações que são socialmente construídas em seu torno. A investigação desenvolvida, embora se situe na área dos estudos culturais, é assumida como de natureza interdisciplinar, buscando uma articulação íntima com os domínios da antropologia cultural e dos estudos literários. A perspectiva interdisciplinar, mais do que acertada, revela a crucial importância de uma abordagem epistemológica abrangente, cruzando teorias e metodologias, no sentido de uma aproximação a um objecto multifacetado.

3 A autora parte da noção de cultura popular para, de alguma forma, proceder à desconstrução de um conceito que, como sublinha, "sofre desde a origem de uma ambiguidade semântica" (p.9). Este processo de questionamento do conceito é realizado a partir dos mecanismos de fabricação social e cultural dos imaginários em redor do moliceiro e dos seus painéis, que são, como comprova a autora, histórica e ideologicamente condicionados. Daí que o moliceiro e a narrativa pictórica que este exibe tenham de ser descodificados no âmbito de um contexto local que envolve múltiplos agentes sociais, com as suas biografias e condições de vida mas, igualmente, no âmbito de dinâmicas de representação e de produção de discursos ideológicos orbitando em torno da localização e função simbólica do povo e das suas artes. A história do moliceiro revela bem como este foi sendo apropriado por diferentes instâncias, poderes públicos e privados, que contribuíram para as variações funcionais e simbólicas que este foi adquirindo.

4 A obra organiza-se em três partes bem distintas. Uma primeira parte, intitulada "Ria de Aveiro: espaço e economia", é constituída por uma análise exaustiva da composição económica, social e demográfica das comunidades lagunares da Ria de Aveiro ao longo dos tempos, situando nitidamente a interligação funcional entre as condições e hábitos quotidianos das gentes locais e o moliceiro. A secção seguinte, com o título "A cultura popular e o barco moliceiro", procede a uma descrição pormenorizada desta embarcação, enunciando técnicas e tecnologias, práticas e protagonistas. Esta secção apresenta, também, uma análise orientada para os painéis decorativos, enquanto narrativas visuais articulando iconografia e mensagem escrita. A última parte, intitulada "A representação etnográfica", faz, em primeiro lugar, um exame crítico aos discursos etnográficos tendo por objecto as culturas populares e, em especial, as gentes do mar e da região, desvendando a natureza claramente ideológica e politicamente motivada de muitos dos enunciados supostamente científicos, para de seguida desvelar os processos de construção da tradição que motivaram uma "refuncionalização" do moliceiro, agora objecto imbuído de renovados significados culturais.

5 É ainda de sublinhar, pela escassa representatividade destes suportes na publicação e divulgação de conteúdos de natureza académica em ciências sociais, a inclusão de um CD-Rom que acompanha o texto escrito. A informação apresenta-se segmentada num CD Imagens ("Antropologia da cultura popular portuguesa: o caso da região de Aveiro" colecção de 1400 imagens) e numa Base de dados ("Inventário dos barcos moliceiros de Aveiro" - totalidade dos barcos moliceiros registados ao longo do século XX). A base de dados, sendo imprescindível para um estudioso da matéria, é menos interessante para o leitor comum. Fundamental é, no entanto, a exploração da vasta base fotográfica que complementa o texto escrito do livro e que serve de suporte imagético à história do moliceiro e à sua esfera de produção e uso. 
6 Questionando a visão tantas vezes ingénua, romântica ou ideologicamente condicionada que serve a edificação dos discursos sobre a chamada arte popular, esta obra tem o mérito de revelar quão importante é uma averiguação empiricamente fundamentada, incidindo sobre diferentes contextos e actores que concorrem para a criação das imagens e imaginários acerca dos artefactos e artes populares. A pesquisa demonstra que as artes do quotidiano local não estão imunes a processos políticos, simbólicos e económicos mais globais, que nos endereçam para outras esferas analíticas. A arte popular não se constitui, portanto, como um repositório estático representando a autenticidade ontológica de uma comunidade, mas antes como um produto de movimentos diversos, por vezes ambíguos e contraditórios, que percorrem os circuitos da fabricação dos mitos nacionais, da invenção da tradição ou do consumo turístico.

\section{AUTORES}

\section{RICARDO CAMPOS}

CEMRI - Universidade Aberta 